\title{
PERBANDINGAN PERENCANAAN PEMBANGUNAN NASIONAL SEBELUM DAN SESUDAH AMANDEMEN UNDANG-UNDANG DASAR 1945
}

\section{Comparison of National Development Planning Before and After Amendment of Constitution 1945}

\author{
Yessi Anggraini \\ PT. BPR Syariah Harta Insan Karimah, Tangerang \\ email: mulilampung00@gmail.com \\ Armen Yasir, Zulkarnain Ridlwan \\ Fakultas Hukum, Universitas Lampung \\ email: armen@unila.ac.id \\ email: zulkarnainridlwan@gmail.com
}

\begin{abstract}
Comparing national development planning as the state policy in the broad outlines in the period before and after the amendment of the Constitution 1945 (UUD 1945) as well as to analyze the position of national development planning guidelines were created after the amendment of the Constitution 1945. Based normative juridical approach, by examining all the rules legislation relating to the legal issues is researched concluded that the First, there are some similarities and differences in the Platform for National Development Planning in the period before and after the 1945 amendment, as for the equation is the substance of the two, whereas the difference lies in the pattern of policy-making, as well as law formulation. Second, the Status Law on National Development Planning System (SPPN) and the regulations under it is official documents which contain the cornerstone of development planning in the era of reforms as a change of planning from documents in the past.
\end{abstract}

Keywords: National Development Planning System, the Constitution 1945

\section{abstrak}

Membandingkan perencanaan pembangunan nasional sebagai haluan negara dalam garis-garis besar pada masa sebelum dan sesudah amandemen Undang-Undang Dasar 1945 (UUD 1945) serta menganalisis kedudukan pedoman perencanaan pembangunan nasional yang dibuat pasca amandemen UUD 1945. Berdasarkan pendekatan yuridis normatif, dengan menelaah segala peraturan perundang-undangan yang terkait dengan pokok masalah yang diteliti disimpulkan bahwa Pertama, terdapat beberapa persamaan dan perbedaan pada Landasan Perencanaan Pembangunan Nasional pada masa 
sebelum dan sesudah amandemen UUD 1945, adapun persamaannya adalah pada substansi dari keduanya, sedangkan perbedaannya terletak pada pola penyusunan kebijakan, serta formulasi hukum. Kedua, Kedudukan UndangUndang Sistem Perencanaan Pembangunan Nasional (SPPN) maupun peraturan dibawahnya adalah dokumen-dokumen resmi yang memuat tentang landasan perencanaan pembangunan pada era refomasi sebagai pengganti dari dokumen perencanaan pada masa sebelumnya.

Kata Kunci : Perencanaan Pembangunan Nasional, Undang-Undang Dasar 1945

\section{A. Pendahuluan}

Pasal 6 Ayat (2) UUD 1945 sebelum amandemen menyatakan bahwa "Presiden dan Wakil Presiden dipilih oleh berdasarkan suara terbanyak." Berdasarkan ketentuan ini, maka presiden terpilih ditetapkan sebagai mandataris Majelis Permusyawaratan Rakyat (MPR) yang dalam menjalankan pemerintahan harus bertanggungjawab kepada MPR. Pasal 3 UUD 1945 menyatakan bahwa, "Majelis Permusyawaratan Rakyat Menetapkan Undang-Undang Dasar dan garis-garis besar daripada haluan negara".

Menurut Mahmuzar, ${ }^{1}$ presiden menjalankan program pembangunan berdasarkan Garis-Garis Besar Haluan Negara (GBHN) yang dikeluarkan melalui Ketetapan MPR (TAP MPR), karena MPR dianggap sebagai maket atau miniatur dari masyarakat Indonesia dalam melakukan proses kedaulatan rakyat. Presiden harus menjalankan haluan negara menurut GBHN yang ditentukan oleh MPR. Di bawah MPR, presiden ialah penyelenggara pemerintah negara yang tertinggi dalam menjalankan pemerintahan negara. ${ }^{2}$ Instrumen hukum dalam acuan penyelenggaraan negara dituangkan dalam bentuk GBHN dalam formulasi Ketetapan Majelis Permusyawaratan Rakyat Republik Indonesia (TAP MPR RI).

Berdasarkan konstruksi pada UUD 1945 sebelum amandemen ini menimbulkan beberapa kondisi sebagai berikut pertama, kekuasaan tertinggi di tangan MPR. Kedua, timbul kekuasaan yang sangat besar pada presiden karena pada Pasal 5 dan Pasal 20 UUD 1945 sebelum amandemen, Dewan Perwakilan Rakyat (DPR) seharusnya berwenang mengontrol presiden dalam penyusunan undang-undang, peran DPR saat itu lebih bertindak sebagai pendukung presiden daripada pengawas presiden, DPR tidak menggunakan hak menyatakan pendapat dan hak inisiatif untuk membuat

\footnotetext{
${ }^{1}$ Mahmuzar, Sistem Pemerintahan Indonesia Menurut UUD 1945 Sebelum dan Sesudah Amandenen, (Bandung: Nusa Media), hlm. 72.

${ }^{2}$ Penjelasan UUD 1945 sebelum amandemen.
} 
undang-undang. Ketiga, rumusan UUD 1945 tentang semangat penyelenggara negara belum cukup didukung dengan konstitusi.

Dalam rangka mewujudkan tuntuan reformasi untuk menyempurnakan aturan dasar mengenai tatanan negara, kedaulatan rakyat, pembagian kekuasaan, kesejahteraan sosial dan hal-hal lain sesuai dengan perkembangan aspirasi dan kebutuhan bangsa, dilakukanlah amandemen terhadap UUD 1945 dengan beberapa kesepakatan dasar diantaranya tidak mengubah Pembukaan UUD 1945; tetap mempertahankan Negara Kesatuan Republik Indonesia; Penjelasan UUD 1945 yang memuat hal-hal normatif akan dimasukkan ke dalam pasal-pasal; perubahan dilakukan secara adendum, dan mempertegas sistem pemerintahan presidensiil. ${ }^{3}$

Konsekuensi dari penguatan sistem pemerintahan presidensiil, terdapat pemangkasan kewenangan MPR, akibat dari pemilihan Presiden secara langsung sehingga tidak ada lagi hubungan antara presiden dan MPR, presiden tidak perlu lagi menyampaikan pertanggungjawaban kepada MPR. MPR tidak lagi berwenang meminta pertanggungjawaban Presiden kecuali jika ada usul dari DPR. ${ }^{4}$ Dengan diberlakukannya UUD 1945 hasil amandemen, terjadi pula perubahan dalam pengelolaan pembangunan, yaitu:

1. penguatan kedudukan lembaga legislatif dalam penyusunan Anggaran Pendapatan dan Belanja Negara (APBN);

2. ditiadakannya Garis-garis Besar Haluan Negara (GBHN) sebagai pedoman penyusunan rencana pembangunan Nasional; dan

3. diperkuatnya Otonomi Daerah dan desentralisasi pemerintahan dalam Negara Kesatuan Republik Indonesia. ${ }^{5}$

Selain daripada itu, dengan berlakunya Undang-Undang Nomor 22 Tahun 1999 tentang Pemerintahan Daerah, penyelenggaraan otonomi daerah dilaksanakan dengan memberikan kewenangan yang luas, nyata, dan bertanggung jawab kepada daerah. Pemberian kewenangan yang luas kepada daerah memerlukan koordinasi dan pengaturan untuk lebih mengharmoniskan dan menyelaraskan pembangunan, baik pembangunan nasional, pembangunan daerah maupun pembangunan antar daerah. Desentralisasi dan penguatan otonomi daerah berpotensi mengakibatkan perencanaan pembangunan daerah tidak sinergi antara daerah yang satu dengan daerah yang lainnya serta antara pembangunan daerah dan pembangunan secara nasional, maka dibutuhkan pengaturan lebih lanjut bagi proses perencanaan pembangunan nasional.

Berdasarkan pertimbangan-pertimbangan tersebut, dirancang undangundang yang mengatur tentang Sistem Perencanaan Pembangunan Nasional

\footnotetext{
${ }^{3}$ Bahan Tayangan MPR..., Ibid.

${ }^{4}$ Ibid., hlm. 93.

5 Penjelasan Umum Undang-Undang Republik Indonesia Nomor 25 Tahun 2004 tentang Sistem Perncanaan Pembangunan Nasional.
} 
untuk menjamin agar kegiatan pembangunan berjalan efektif, efisien, dan bersasaran. Undang-undang ini mencakup landasan hukum di bidang perencanaan pembangunan baik oleh pemerintah pusat maupun pemerintah daerah.

Adanya perubahan landasan perencanaan pembangunan nasional pada haluan negara dalam garis-garis besar sebagai pedoman penyusunan rencana pembangunan nasional, menyebabkan timbulnya ambiguitas terhadap perencanaan pembangunan nasional di era sebelum dan sesudah amandemen UUD 1945. Oleh sebab itu perlu adanya pengkajian dan analisis mengenai perbandingan landasan perencanaan pembangunan sebelum dan setelah amandemen UUD 1945 sebagai wujud dari upaya-upaya menjalankan menyelenggarakan kepentingan negara dan kesejahteraan rakyat sebagai pemegang kedaulatan. Bagaimana perbandingan secara substansi, pola penyusunan serta formulasi payung hukumnya dan bagaimana kedudukan Undang-Undang Nomor 25 Tahun 2004 tentang Sistem Perencanaan Pembangunan Nasional (SPPN) sebagai landasan perencanaan pembangunan nasional pasca amandemen UUD 1945?

Penulisan ini menggunakan pendekatan yuridis. Metode pendekatan yuridis digunakan untuk mengkaji atau menganalisis data sekunder yang berupa bahan-bahan hukum, terutama bahan-bahan hukum primer dan bahan-bahan hukum sekunder. ${ }^{6}$ Dalam penelitian ini diterapkan pendekatan undang-undang (statute approach $)^{7}$ dengan menelaah semua undang-undang dan regulasi yang bersangkut paut dengan isu hukum.

\section{B. Pembahasan}

\section{Perbandingan Landasan Perencanaan Pembangunan Nasional Sebelum dan Sesudah Amandemen UUD 1945 \\ a. Perbandingan Perencanaan Pembangunan Nasional dari Proses Perancangan Kebijakan.}

Penyusunan rencana pembangunan dipioritaskan untuk mengakomodir kepentingan dan kebutuhan rakyat, terdapat beberapa perbedaan antara landasan perencanaan pembangunan pada masa sebelum dan sesudah amandemen UUD 1945.

Alur penyusunan rencana pembangunan pada era reformasi ditetapkan sedemikian rupa guna menghasilkan susunan perencanaan yang bersifat sistematis, berkesinambungan, dan aplikatif sesuai dengan aspirasi dengan partisipasi berbagai elemen bangsa didalamnya. Sesuai dengan amanat dari Undang-Undang Nomor 25 Tahun 2004, perencanaan pembangunan terdiri

\footnotetext{
${ }^{6}$ Ronny Hanitijo Soemitro, Metodologi Penelitian Hukum dan Jurimetri, (Jakarta : Ghalia Indonesia, 1988), hlm. 11-12.

${ }^{7}$ Peter Mahmud Marzuki, Penelitian Hukum, (Jakarta: Kencana, 2010), hlm. 93.
} 
dari empat tahapan yakni penyusunan rencana; penetapan rencana; pengendalian pelaksanaan rencana; dan evaluasi pelaksanaan rencana. Keempat tahapan diselenggarakan secara berkelanjutan sehingga secara keseluruhan membentuk satu siklus perencanaan yang utuh.

Perencanaan di era reformasi penyusunannya diatur secara lebih rinci dan sistematis. RPJM Nasional merupakan penjabaran dari visi, misi, dan program Presiden yang penyusunannya berpedoman pada RPJP Nasional, memuat strategi pembangunan nasional, kebijakan umum, program Kementerian/Lembaga dan lintas Kementerian/Lembaga, kewilayahan dan lintas kewilayahan, serta kerangka ekonomi makro yang mencakup gambaran perekonomian secara menyeluruh termasuk arah kebijakan fiskal dalam rencana kerja yang berupa kerangka regulasi dan kerangka pendanaan yang bersifat indikatif.

Tahapan penyusunan RPJM dimulai dari penyiapan rancangan awal RPJM Nasional oleh MENTERI PERENCANAAN dalam hal ini dilaksanakan oleh Bappenas sebagai lembaga yang bertanggung jawab mengkoordinasikan perencanaan pembangunan secara nasional; Penyiapan rancangan Rencana Strategis Kementrian/Lembaga (rancangan Renstra-KL), yang dilakukan oleh seluruh kementerian dan lembaga. Penyusunan rancangan Renstra ini bertujuan untuk merumuskan visi, misi, tujuan, strategi, kebijakan, program dan kegiatan pembangunan yang sesuai dengan tugas dan fungsi kementerian/lembaga, agar selaras dengan program prioritas kepala negara terpilih.

Kemudian penyusunan rancangan RPJM Nasional oleh Kementerian Perencanaan sebagai upaya mengintegrasikan rancangan awal RPJM Nasional dengan rancangan Renstra-KL; penyelenggaraan Musyawarah Perencanaan Pembangunan (Musrenbang) jangka menengah nasional dan penyusunan Rancangan Akhir RPJM Nasional. Renstra-KL memuat visi, misi, tujuan, strategi, kebijakan, program, dan kegiatan pembangunan sesuai dengan tugas dan fungsi Kementerian/Lembaga yang disusun dengan berpedoman pada RPJM Nasional dan bersifat indikatif. Kemudian dari Renstra tersebut dibuat bentuk konkrit pelaksanaannya dalam bentuk Rencana Kerja Kementerian Lembaga (Renja-KL).

Renja-KL disusun berpedoman pada Renstra-KL yang telah ada lebih dulu dan mengacu pada prioritas pembangunan nasional. Penyusunan RenjaKL dilakukan secara bersamaan dengan penyusunan Rencana Kerja Pemerintah (RKP) karena keduanya saling terkait. RKP adalah perencanaan yang meliputi periode satu tahun yang dalam hal ini sebagai Rencana Pembangunan Jangka Tahunan dan merupakan penjabaran dari RPJM Nasional. RKP berisi prioritas pembangunan, rancangan kerangka ekonomi makro yang mencakup gambaran perekonomian yang menyeluruh termasuk kebijakan fiskal, serta program Kementerian/Lembaga, lintas 
Kementerian/Lembaga, kewilayahan dalam bentuk kerangka regulasi dan kerangka pendanaan yang masih bersifat indikatif. ${ }^{8}$ Dari RKP inilah kemudian dijadikan pedoman menyusun Rencana Anggaran Pendapatan Belanja Negara (RAPBN) dan dibuat kebijakan melalui Undang-Undang Anggaran Pendapatan dan Belanja Negara (APBN) sebagai bentuk nyata dari pelaksanaan pembangunan. Begitu pula dengan di pemerintahan daerah, menggunakan sistematika yang sama yang telah diatur di Undang-Undang SPPN yang secara singkat hampir sama dengan proses kebijakan pembangunan nasional.

Dari uraian tersebut jika dibandingkan dengan GBHN nampak sekali perbedaan siklus perencanaan pembangunan antara yang dimuat di GBHN dan SPPN. Pada masa sebelum amandemen, proses perancangan perencanaan pembangunan hanya sampai pada tahap Repelita dan diwujudkan secara konkrit dalam poin-poin Sasaran Pembangunan Lima Tahun (Sarlita). Kemudian arahan dari Sarlita tersebut digunakan sebagai bahan acuan untuk merancang APBN sebagai salah satu bentuk pelaksanaan kebijakan pembangunan tahunan. Pada masa itu tidak diatur secara rinci bagaimana hubungan kinerja pembangunan yang harus dilakukan antar lembaga di tingkat nasional, dan tidak juga dibuat rancangan sistem yang mengarahkan koordinasi pembangunan di daerah.

Mekanisme atau alur penyusunan rencana pembangunan nasional pada dasarnya memiliki tujuan yang sama, yakni berkomitmen melibatkan partisipasi masyarakat yang luas dan kekuatan-kekuatan politik di parlemen untuk mewujudkan pembangunan nasional yang dapat menciptakan kesejahteraan umum, dan mencapai cita-cita kemerdekaan bangsa. Akan tetapi, setelah dilakukan analisis perbandingan, terlihat bahwa penyusunan rencana pembangunan di era reformasi telah diupayakan untuk lebih melengkapi perencanaan pada masa sebelumnya. Hal ini terlihat dari rincian sistematika penyusunan yang lebih teratur dan terarah sebagaimana yang diamanatkan dalam Undang-Undang SPPN.

\section{b. Perbandingan Perencanaan Pembangunan Nasional dari Segi Substansi}

Ditinjau dari segi substansi, ternyata dokumen landasan perencanaan pembangunan nasional pasca amandemen UUD 1945 tidak jauh berbeda dengan dokumen GBHN yang dikeluarkan melalui TAP MPR. Banyak kesamaan dalam penjabaran hal-hal yang diatur untuk dilaksanakan oleh penyelenggara pemerintahan dalam pembangunan.

\footnotetext{
${ }^{8}$ Pasal 4 Undang-Undang Nomor 25 Tahun 2004 tentang Sistem Perencanaan Pembangunan Nasional.
} 
Pada pola dasar maupun sistem perencanaan pembangunan landasan sebelum dan sesudah amandemen UUD 1945 pada hakikatnya memiliki tujuan dan fungsi yang sama yaitu sebagai tata cara pelaksanaan pembangunan nasional, yang berisi nilai-nilai dasar tujuan pembangunan yang tidak dibatasi kurun waktu dalam keberlakuannya. Pola ini mengatur garis kebijakan dan sistem perencanaan pembangunan untuk dijabarkan dalam bentuk perencanaan pembangunan jangka panjang, menengah maupun tahunan.

Materi yang dimuat di dalam kedua landasan pola pembangunan tersebut tidak jauh berbeda yakni mengenai asas-asas pembangunan, tujuan pembangunan nasional. Asas-asas pembangunan yang dimuat dalam SPPN hampir sama dengan GBHN hanya menggunakan redaksional yang lebih sederhana dan efisien. Untuk tujuan dan ruang lingkup pembangunan nasional yang ditentukan, pada hakikatnya mengandung kesamaan unsur, karena berpedoman pada tujuan negara dalam UUD 1945.

\section{c. Perbandingan Landasan Hukum Perencanaan Pembangunan Nasional dari Segi Formulasi Landasan Hukum}

Perbedaan yang krusial dan kini menjadi dilema di masyarakat mengenai landasan hukum perencanaan pembangunan nasional adalah formulasi kebijakan melalui produk hukum yang ada. Sebelum amandeman TAP MPR/S dianggap lebih tinggi dari undang-undang karena dibuat oleh lembaga tertinggi negara yang menetapkan undang-undang. Dalam hal ini dapat dikatakan bahwa TAP MPR merupakan bentuk dari penafsiran terhadap konstitusi.

Pada masa setelah amandemen UUD 1945 karena MPR tidak lagi membuat GBHN untuk dilaksanakan oleh Presiden, maka perubahan kewenangan MPR yang berlaku keluar membawa akibat perubahan pada kedudukan dan status hukum Ketetapan MPR. Perubahan tata urutan peraturan perundang-undangan yang diatur dalam Undang-Undang Nomor 12 Tahun 2011 tentang Pembentukan Peraturan Perundang-Undangan, TAP MPR bukan lagi termasuk peraturan perundang-undangan, karena TAP MPR yang masih diberlakukan adalah ketetapan yang bersifat penetapan dan tidak mengenai ketatanegaraan.

Pola dasar pembangunan pada masa sebelum amandemen UUD 1945 dimuat dalam dokumen GBHN diformulasikan dalam TAP MPR yang tetapkan setiap lima tahun sekali mengingat dinamik masyarakat yang diperhatikan oleh majelis. GBHN menentukan arah kebijakan pembangunan yang hendak dilaksanakan Presiden. TAP MPR menjadi formulasi GBHN pada masa itu adalah sebagai keputusan negara yang merupakan peraturan perundang-undangan di bidang ketatanegaraan dan memunyai kekuatan hukum mengikat keluar dan ke dalam MPR. TAP MPR tentang GBHN 
bersifat abstrak dan mengikat secara umum, dan dari segi keberlakuannya bersifat tidak sekali jalan (einmalig) namun tetap berlaku dengan ketentuan.

Sedangkan aturan mengenai pola pembangunan nasional setelah amandemen UUD 1945 diformulasikan dalam Undang-Undang Nomor 25 Tahun 2004 tentang Sistem Perencanaan Pembangunan (SPPN) yang dibuat oleh lembaga legislatif berdasarkan prinsip kedaulatan rakyat. Undangundang SPPN tersebut dirancang oleh DPR sebagai badan dengan prinsip keterwakilan rakyat dan disahkan bersama dengan Presiden.

Pola pembangunan jangka panjang yang diatur melalui TAP MPR, pada dasarnya adalah norma yang bersifat umum. Akan tetapi kebijakan pengaturan tersebut dikeluarkan melalui ketetapan yang sacara hakikat adalah sama dengan keputusan. Ketetapan hanya merupakan tindakan hukum yang memunyai akibat menciptakan, mengubah, membatalkan suatu hubungan hukum. Produk hukum yang bersifat penetapan dan digunakan penyebutan "Ketetapan" tidak dapat mengandung materi normatif yang bersifat pengaturan."

Seharusnya, pengaturan mengenai haluan pembangunan jangka panjang ditetapkan melalui suatu bentuk hukum sendiri karena merupakan perencanaan yang menggambarkan visi, misi, tujuan, sasaran, program pembangunan untuk kurun waktu tertentu dan tetap berlaku dengan ketentuan. Arahan pembangunan jangka panjang adalah suatu bentuk peraturan pelaksana dari apa yang telah atur dalam Kebijakan dalam pola dasar pembangunan dalam dokumen GBHN di TAP MPR .

Sedangkan pada haluan pembangunan jangka panjang di era reformasi kebijakan peraturan ditetapkan dengan undang-undang untuk tingkat pusat, dan peraturan daerah di tingkat daerah. Undang-Undang RPJP Nasional menyebutkan dengan tegas ruang lingkup materi yang diatur yakni penjabaran dari Undang-Undang SPPN, sebagai teknis yang mengarahkan kebijakan pada jangka waktu 20 tahun mendatang.

Untuk pembangunan lima tahunan, pada GBHN dicantumkan hanyalah Pola Umum Pembangunan Lima Tahunan kemudian dibuat Repelita. Repelita yang ditetapkan dalam Keputusan Presiden berdasarkan Pola Umum Pelita yang disusun oleh MPR. Repelita merupakan suatu keputusan administrasi negara atau penyelenggaraan pemerintahan, yang termasuk dalam keputusan yang bersifat perencanaan (plannen) yakni merupakan peraturan perancanaan yang menggambarkan visi, misi tujuan, sasaran, program pembangunan untuk kurun waktu tertentu.

Dalam praktik ketatanegaraan Indonesia sebelumnya, memang di dalam jenis dan tata urutan (susunan) peraturan perundang-undangan yang

\footnotetext{
${ }^{9}$ Jimly Asshiddiqie dalam Perihal Perihal Undang-Undang di Indonesia, (Jakarta: Konpres, 2006), hlm. 20.
} 
diatur dalam Ketetapan MPRS No. XX/MPRS/1996 belum dikenal bentuk hukum Peraturan Presiden, hanya disebutkan di dalam hierarki tersebut Peraturan Pemerintah begitu pula pada Ketetapan MPR No. III/MPR/2000 yang belum mencantumkan Peraturan Presiden dalam hierarki dan jenis peraturan perundang-undangan. Pada masa orde baru sampai dengan tahun 2004, yang dikenal dengan bentuk hukum Keputusan Presiden dapat bersifat mengatur (berupa peraturan perundang-undangan) maupun bersifat ketetapan.

Setelah amandemen UUD 1945 rencana pembangunan lima tahunan yang disebut dengan RPJM yang ditetapkan dengan Peraturan Presiden atau Peraturan Kepala Daerah. RPJM Nasional/Daerah merupakan penjabaran visi misi presiden/kepala daerah yang terpilih dengan konteks yang mengacu kepada skala proiritas pembangunan nasional yang telah ditetapkan dalam Undang-Undang RPJP Nasional atau Peraturan Daerah Tentang RPJP Daerah.

Sebagai penjabaran dan pelaksanaan dari RPJP tersebut pemerintah diharuskan menyusun Rencana Pembangunan Jangka Menengah (RPJM) dengan periode pelaksanaan selama 5 tahun yang itu ditetapkan dengan Peraturan Presiden dan Peraturan Kepala Daerah. RPJP disusun berdasarkan visi dan misi presiden yang telah terpilih melalui pemilu. Sehingga diakhir masa jabatan, yang sebelumnya pelakasanaan Pelita pada masa sebelum amandemen dipertanggungjawabkan kepada MPR sebagai pemberi mandat, saat ini Pembangunan Jangka Menengah/Lima Tahun pada era reformasi dipertanggungjawabkan oleh Presiden/Kepala Derah kepada rakyat yang notabenenya adalah sebagai pemberi mandat melalui pemilihan umum.

\section{Undang-Undang SPPN sebagai Landasan Perencanaan Pembangunan Nasional Pasca Amandemen UUD 1945}

Diformulasikannya dokumen landasan perencanaan sebagai pengganti GBHN pada masa setelah amandemen UUD 1945 banyak menimbulkan pro dan kontra di kalangan masyarakat. Beberapa alasan kontraproduktif yang banyak dikemukakan oleh tokoh-tokoh masyarakat dalam berbagai diskusi publik diantaranya membahas kedudukan landasan perencanaan pembangunan pasca amandemen yakni Undang-Undang SPPN, maupun RPJP dan RPJM yang dianggap tidak sebanding dengan GBHN sebagai landasan perencanaan pembangunan pada masa orde baru.

Dengan dihapuskannya GBHN, konsistensi dan kontinuitas nampak tidak berjalan karena perencanaan pembangunan diwadahi dalam undangundang. Undang-Undang SPPN beserta peraturan dibawahnya yang menjadi landasan perencanaan pembangungan saat ini, dianggap tidak dapat menjamin kesinambungan dan keselarasan pembangunan antara pusat dan daerah. 
Fenomena sinkronisasi pelaksanaan pembangunan antara pusat dan daerah dan antar daerah dinilai tidak ada karena pelaksanaan berjalan sendiri-sendiri. Dalam hal ini Presiden Direktur Center for Election and Political Party (CEPP) Chusnul Mariyah mengemukakan,

"jika arah pembangunan menurutnya tidak cukup dituangkan dalam misi dan visi calon presiden yang bila terpilih kemudian dituangkan dalam undang-undang. Jika tidak adanya kejelasan arah maka program pembangunan bisa ditafsirkan secara bebas dan ini sudah terjadi di mana kepala daerah menafsirkan sendiri-sendiri pembangunan di wilayahnya" 10

Dengan berbagai alasan yang dikemukakan, muncul paradigma bahwa sangat diperlukan konsensus politik, dalam membuat arah pembangunan, yang lebih tinggi daripada undang-undang. Adanya GBHN atau memakai nama yang lain dalam menentukan arah pembangunan adalah sesuatu yang penting sebab nasib bangsa yang besar ini dianggap akan terdistorsi apabila ditentukan oleh visi dan misi dari presiden, gubernur, walikota, dan bupati. Selain itu, beberapa tokoh berpendapat jika ke depan kiblat bangsa harus dibenahi. Legal banding untuk pedoman perencanaan pembangunan nasional harus dibuat lebih tinggi agar memiliki daya ikat yang legal, psikologis, dan ideologis. Dengan daya ikat yang tinggi maka setiap komponen bangsa akan memunyai komitmen yang tinggi dan sense of respon yang baik.

Dalam rangka penjabaran amanat UUD 1945 untuk mewujudkan kesejahteraan guna mencapai tujuan negara, diperlukan kebijakan pembangunan yang terarah. Pasca amandemen GBHN dihapuskan dan pemerintah merasa perlu membuat kembali pedoman perancangan maupun pelaksanaan pembangunan nasional. Oleh karena pada masa setelah amandemen kewenangan semua lembaga negara bersifat neben, maka penetapan kebijakan arah pembangunan ditetapkan dengan produk hukum nasional berupa peraturan perundang-undangan yang bersifat mengikat, umum, menyeluruh, sistematis, serta bertanggung jawab untuk dapat dilaksanakan oleh para penyelenggara negara.

Kebijakan arahan pembangunan pada era reformasi ditetapkan melalui Undang-Undang Nomor 25 Tahun 2004 Tentang Sistem Perencanaan Pembangunan Nasional (SPPN), sebagai instrumen hukum yang mengatur hal-hal lebih lanjut mengenai penyelenggaraan negara, pemerintahan dan pembangunan dari ketentuan UUD 1945 yang masih bersifat sangat umum. Materi yang diatur dalam undang-undang ini bersifat ketatanegaraan. Dari segi penyusunan undang-undang ini dapat dikatakan konsisten secara intern maupun ekstern. Hal tersebut dapat dilihat dari hubungan sistematik antara kaidah-kaidahnya, kebakuan susunan serta bahasa. Selain itu, undang-

\footnotetext{
${ }^{10}$ Chusnul Mariyah, GBHN dan Urgensinya di Masa Depan, pada http://www.mpr.go.id/berita/read/2013/10/03/12708/sosialisasi-4-pilar-di-kampus-kuning 03/12/2013 12: 02 .
} 
undang ini mengatur hubungan harmonisasi antara pendelegasian kewenangan dari undang-undang tersebut terhadap peraturan dibawahnya.

Dalam Undang-Undang SPPN yang dirancang untuk menggantikan GBHN, sudah diterapkan prinsip hierarki dan teori pendelegasian kewenangan perundangan. Di mana undang-undang tersebut hanya menjabarkan secara garis besar, kaidah-kaidah yang bersifat abstrak mengenai penyusunan perencanaan pembangunan nasional untuk jangka panjang, menengah dan tahunan. Sementara itu dalam pelaksanaannya undang-undang ini masih memerlukan aturan yang bersifat lebih teknis sebagai bentuk rancangan riil dari perencanaan pembangunan. Undangundang ini sifatnya hanya sebagai bahan pedoman dalam penyusunan perencanaan yang keberlakuannya tidak berdasarkan jangka waktu tertentu.

Banyak kritik yang menyampaikan bahwa dengan dibuatnya pedoman pelaksanaan pembangunan nasional masa kini tidak mengandung unsur kontinuitas maupun konsistensi pelaksanaan akibat bentuk instrumen hukumnya berupa undang-undang. Tidak ada sinkronisasi dalam penjabaran rencana pembangunan di undang-undang satu dengan lainnya. Secara hakikat, kedudukan Undang-Undang SPPN adalah sebagai peraturan pelaksana yang menjabarkan amanat UUD 1945, sehingga undang-undang ini menjadi peraturan tertinggi setelah UUD 1945 untuk dijadikan pedoman pembangunan.

Undang-Undang SPPN mengatur tentang rencana pembangunan yang akan disusun baik dari segi prosedur penyusunan, pembahasan dan penetapannya hingga menjadi program kebijakan legislasi nasional. RPJP sebagai rancangan program jangka panjang harus ditetapkan dengan undangundang/peraturan daerah sedangkan RPJM sebagai rancangan program pembangunan jangka menengah harus ditetapkan dengan Peraturan Presiden/Peraturan Kepala Daerah.

Meskipun diatur dengan dokumen terpisah, yang secara hierarkis sejajar dengan Undang-Undang SPPN, namun RPJP adalah merupakan satu kesatuan yang disusun berpedoman penuh terhadap Undang-Undang SPPN, sifatnya merupakan pelaksana ketentuan Undang-Undang SPPN. Pedoman penyusunannya sudah diatur secara rinci di dalam ketentuan-ketuan yang ada di dalam pasal-pasal Undang-Undang SPPN. Materi yang diatur secara subtansisal pun jika dicermati tidak menyimpangi atau bertentangan dengan Undang-Undang SPPN. Undang-Undang RPJP memuat kondisi umum, arahan, tahapan sampai pada prioritas secara konkrit untuk jangka panjang.

Kedua undang-undang tersebut dapat dikatakan tidak menimbulkan peluang inkosistensi secara horizontal dari segi subtansi peraturan. Ruang lingkup materi yang diatur jelas, sehingga tidak terjadi pengulangan norma yang telah diatur didalam peraturan perundangan yang mendelegasikan terhadap peraturan pelaksananya. Undang-Undang RPJP memuat kondisi 
umum, arahan, tahapan sampai pada prioritas secara konkrit. Kebijakan arah pembangunan jangka panjang di daerah yang disebut dengan Rencana Pembangunan Jangka Panjang Daerah (RPJP Daerah) ditetapkan dengan Peraturan Daerah. Kebijakan ini merupakan suatu bentuk upaya perwujudan pembangunan yang berimbang antara pusat dan daerah dalam rangka pelaksanaan otonomi daerah dengan asas pembantuan. Mekanisme penyusunan dan penetapan RPJP Daerah ini pun telah diatur pada sistem perencanaan pembangunan nasional agar sesuai dengan arah kebijakan negara. Perancangan substansinya juga diharuskan untuk mengacu kepada arahan dari RPJP Nasional.

RPJP Nasional diyakini tidak akan optimal untuk menjadi rujukan utama perencanaan pembangunan nasional. RPJM Nasional tidak dapat menjamin bahwa penyusunan dan substansinya dapat sesuai dngan RPJP Nasional. Selain itu, kebijakan ini dianggap cenderung lebih mencerminkan visi personal presiden sehingga dikatakan tidak mewakili aspirasi rakyat dalam menentukan arah pembangunan.

Berdasarkan rumusan tujuan yang duraikan dalam Undang-Undang SPPN maka jika semua komponen pelaku pembangunan bangsa ini merujuk dengan konsisten kepada tersebut maka masalah-masalah inkonsistensi dalam perencanaan dan pelaksanaan pembangunan, baik jangka panjang, menengah, tahunan, atau pun antara pusat dan daerah maupun antar daerah sendiri, seharusnya tidak terjadi. Karena undang-undang ini menghendaki sebaliknya, yaitu upaya koordinasi di antara elemen-elemen stakeholders pembangunan, di pusat maupun di daerah. Apabila dengan adanya RPJM yang ditetapkan melalui Peraturan Presiden menjadi polemik di masyarakat, kembali dapat dirujuk pada Undang-Undang SPPN.

Mengenai RPJM Daerah, yang dikhawatirkan akan terdistorsi dengan adanya penjabaran visi dan misi kepala daerah, hal tersebut telah ditetapkan pula di dalam Undang-Undang SPPN. RPJM Daerah merupakan penjabaran visi, misi, dan program Kepala Daerah yang penyusunannya berpedoman pada RPJP Daerah dan memperhatikan RPJM Nasional, memuat arah kebijakan keuangan daerah, strategi pembangunan daerah, dan sebagainya. ${ }^{11}$.

Sedangkan, jika dibandingkan dengan pada masa orde baru landasan hukum yang paling dasar setelah UUD 1945 adalah keputusan MPR, salah satu keputusan MPR yang menjadi landasan paling dasar pembangunan adalah GBHN. Mengingat dinamik masyarakat, sekali dalam 5 tahun Majelis memperhatikan segala yang terjadi dan segala aliran-aliran pada waktu itu dan menentukan haluan-haluan apa yang hendaknya dipakai untuk di kemudian hari. Dari penjelasan ini dapat dipahami bahwa GBHN disusun

\footnotetext{
${ }^{11}$ Pasal 5 Undang-Undang Nomor 25 Tahun 2004 Tentang Sistem Perencanaan Pembangunan Nasional.
} 
lima tahun sekali karena alasan untuk mengakomodasi perkembangan dan dinamika paling mutakhir yang berkembang di masyarakat. Dengan demikian diharapkan GBHN akan bersifat responsif terhadap problemproblem masyarakat. Dalam melaksanakan GBHN yang bersifat lima tahunan pemerinah membuat Repelita yang didalamnya termuat rencana teknis pelaksanaan GBHN.

Pada masa berlakunya GBHN adalah di mana rezim orde baru sedang dijalankan ditandai melalui beberapa cirinya yang khas, yaitu secara politik rezim pemerintah berperilaku sangat otoriter, sistem pemerintahan bersifat sentralistik, dan tidak ada pemilihan presiden dan pemilihan kepala daerah langsung. Saat ini, di era reformasi, situasi dan kondisinya sudah sedemikian berubah. Era reformasi ditandai dengan pola demokrasi dan keterbukaan berpendapat. Seperti sistem pemerintahan yang berubah menjadi desentralistis, pemilihan presiden dan pemilihan kepala daerah berlangsung melalui mekanisme pemilihan langsung. Kehidupan yang demokratis begitu terasa, kebebasan berekspresi dan berpendapat demikian terbuka. Maka wajar ketika landasan perencanaan diubah dalam formulasi yang berbeda untuk mengimbangi sistem pemerintahan Indonesia yang juga telah berubah seiring dengan diamandemennya dasar negara. Ditetapkannya landasan hukum perencanaan pembangungan nasional melalui Undang-Undang SPPN justru lebih tepat dan sesuai dengan amanat konstitusi. Undang-undang ini bersifat konsisten menjadi rujukan perencanaan, kemudian mengakomodir pedoman tahapan perencanaan, penyusunan, penetapan dan evaluasi kebijakan pembangunan jangka panjang dan menengah secara berkala.

Selanjutnya, landasan pelaksana perencanaan pembangunan ditetapkan dengan produk hukum yang bersifat mengatur secara resmi dan ditetapkan dengan peraturan perundangan yang hierarkis. Sehingga perencanaan pembangunan nasional tersusun secara sistematis serta dapat disesuaikan dengan dinamika yang berkembang di masyarakat.

Undang-Undang SPPN bersifat tetap, sedangkan GBHN diperbaharui secara periodik yakni lima tahun sekali. Pelaksanaan Undang-Undang SPPN diturunkan dalam bentuk Undang-Undang yang memuat dokumen RPJP dengan periode dua puluh tahun, dan Peraturan Presiden untuk pembangunan jangka lima tahunan. Berkenaan dengan RPJM juga merupakan kebijakan pembangunan berdasarkan visi misi presiden, namun tetap mengacu dan diarahkan dengan skala prioritas di dalam UndangUndang RPJPN, sedangkan dalam Repelita Keputusan Presiden disusun berdasarkan GBHN yang dirancang oleh MPR.

Secara strategis memang kedudukan GBHN pada masa sebelum amandemen lebih tinggi dibanding dengan SPPN yang berstatus sebagai undang-undang. Banyak saran dan masukan agar status RPJPN diangkat dari undang-undang menjadi keputusan MPR untuk menjadikan legal banding 
yang sejajar. Akan tetapi setelah amandemen UUD 1945, dilaksnakan Pemilihan Umum 2004 MPR tidak lagi berwenang menetapkan GBHN dan ketetapan-ketetapan yang bersifat mengatur (regeling) dan mengikat untuk umum seperti sebelumnya. ${ }^{12}$ Satu-satunya produk hukum yang dibuat menurut lingkup kewenangan MPR dan bersifat mengatur dewasa ini adalah produk perubahan undang-undang dasar yang dilakukan menurut ketentuan Pasl 37 Ayat UUD 1945. MPR pasca reformasi tidak lagi memunyai kewenangan untuk menetapkan peraturan di luar undang-undang dasar, maka tidak akan ada lagi produk hukum yang berisi norma yang mengatur yang ditetapkan dengan TAP MPR selain dari perubahan UUD 1945.

Kemudian terkait tanggapan bahwa dengan ditetapkan melalui undang-undang, maka dalam apabila terjadi penyimpangan atau ketidaksesuaian pelaksanaan pembangunan dengan ketentuan yang telah ditetapkan tidak ada sanksi yuridis yang jelas. Perlu dicermati bahwa dokumen SPPN beserta turunannya secara substansi materi yang diatur adalah merupakan peraturan yang mengandung ketentuan dengan sifat directory. Jika undang-undang menentukan waktu tertentu dalam rangka pelaksanaan suatu tugas terntentu maka undang-undang itu dikatakan bersifat directory yang pemenuhannya tidak perlu bersifat formal dan mutlak, tetapi cukup bersifat substansif atau materiil. ${ }^{13}$

Dalam suatu hal ketentuan undang-undang berkaitan dengan pelaksanaan suatu tugas pejabat publik tertentu, pelanggaran terhadapnya sepanjang tidak menimbulkan ketidakadilan yang nyata, tidak menyebabkan batalnya perbuatan yang dilakukan berdasarkan undang-undang yang bersangkutan, dan karenanya ketentuan demikian itu dapat dikatakan bersifat directory. Pelanggaran terhadapnya tidak menimbulkan efek pembatalan, maka pelanggarannya dapat diancam dengan hukuman karena kelalaian.

Tidak jauh berbeda dengan materi dari ketentuan-ketentuan yang diatur dalam GBHN melalui TAP MPR, karena pada hakikatnya hal-hal yang diatur pada GBHN berisi kaidah dan pokok-pokok haluan pembangunan yang sama dengan haluan pembangunan pada era reformasi sekarang. Dengan demikian, dapat ditarik kesimpulan bahwa mengenai sanksi yuridis terhadap jaminan pelaksanaan pembangunan nasional baik sebelum dan sesudah amandemen sama-sama tidak diatur.

\section{Penutup}

\section{Simpulan}

Perbedaan adalah terletak pada pola penyusunan kebijakan, serta formulasi kebijakan dalam bentuk produk hukumnya, sedangkan persamaan

\footnotetext{
${ }^{12}$ Jimly Asshiddiqie, Perihal..., Op. Cit., hlm. 52.

${ }^{13}$ Jimly Asshiddiqie, Perihal..., Op. Cit., hlm. 29.
} 
dari keduanya adalah substansi yang diatur dalam perencanaan-perencanaan tersebut. Kedudukan Undang-Undang SPPN maupun peraturan dibawahnya adalah dokumen-dokumen resmi yang memuat tentang landasan perencanaan pembangunan pada era reformasi sebagai pengganti dari dokumen perencanaan pada masa sebelumnya yaitu GBHN. Adapun pro kontra menyangkut wacana kembalinya GBHN, hanya merupakan dampak dari kurangnya sosialisasi terhadap keberadaan SPPN, RPJP dan RPJM.

\section{Saran}

1. Dokumen perencanaan pembangunan yang telah dirancang pada saat ini sebaiknya tidak hanya dijadikan dokumen tertulis semata, namun harus benar-benar digunakan sebagai arahan dan acuan untuk melaksanakan program secara efektif dan tepat sasaran. Dengan demikian pembangunan dapat dilaksanakan secara sistematis berdasarkan prioritas tujuan yang hendak dicapai, sehingga pembangunan menjadi terarah, terkait satu sama lain di bidang perencanaan, adanya kejelasan target pencapaian, terkoordinir dan berkesinambungan antara pusat dan daerah.

2. Dibutuhkan sosialisasi terhadap dokumen-dokumen tersebut. Hal ini penting agar masyarakat tidak mempertanyakan haluan pembangunan negara. Karena keberadaan Undang-Undang SPPN, RPJP dan RPJM, sesungguhnya merupakan GBHN di era reformasi.

\section{Daftar Pustaka}

Asshiddiqie, Jimly, 2006, Perihal Undang-Undang, Ghalia: Jakarta.

Bahan Tayangan MPR Materi Sosialisasi Undang-Undang Dasar Negara Republik Indonesia Tahun 1945 dan Ketetapan MPR RI, Sekretariat Jendral MPR RI, 2012.

Mahmuzar, 2010, Sistem Pemerintahan Indonesia Menurut UUD 1945 Sebelum dan Sesudah Amandemen, Nusa Media: Bandung.

Makalah "Implikasi Perubahan UUD 1945 Terhadap Sistem Perencanaan Pembangunan Nasional" oleh Deddy Supriady Bratakusumah di unduh pada http://webcache.googleusercontent.com/search?q=cache 4Bpcqw_epCMJ:www.bappenas.go.id/index.php/download_file/view/ 10651/2367/+\&cd=1\&hl=id\&ct=clnk\&gl=id

Undang-Undang Dasar Negara Republik Indonesia Tahun 1945

Undang-Undang Republik Indonesia Nomor 25 Tahun 2004 Tentang Sistem Perncanaan Pembangunan Nasional 